\title{
THE BASE SECTOR OF COMMUNITY PLANTATION PLANT
}

\author{
Nina Maksimiliana Ginting \\ Agribusiness Department, Faculty of Agriculture, \\ Universitas Musamus, Merauke, Indonesia \\ Philipus Betaubun \\ Civil Engineering Department, Faculty of Engineering, \\ Universitas Musamus, Merauke, Indonesia
}

\begin{abstract}
This study aims to determine the commodity of smallholder plantation which became the basis of each district in Deli Derdang Regency. The data used is secondary data. The data analysis used is Location Quotient analysis. The results showed that the commodities of smallholder plantations which became the basis in Deli Serdang Regency were rubber, coconut, coffee, cocoa, cinnamon, areca nut, candlenut, gambier, palm sugar and sugar cane.
\end{abstract}

Keywords: Base, Location Quotient, Smallholder Plantation.

Cite this Article: Nina Maksimiliana Ginting and Philipus Betaubun, The Base Sector of Community Plantation Plant, International Journal of Advanced Research in Engineering and Technology (IJARET), 10 (6), 2019, pp 53-60.

http://iaeme.com/Home/issue/IJARET?Volume $=10 \&$ Issue $=6$

\section{INTRODUCTION}

The Deli Serdang Regency is a well-known area in the Indonesians archipelago, mainly because the country's foreign exchange is derived from the Deli Serdang Regency's potential agricultural products such as rubber, coconut, and oil palm. Deli Serdang Regency carries out sixteen economic sectors, including agriculture, mining, manufacturing, building and others. Each economic sector in Deli Serdang Regency contributes different in GRDP contributions (BPS, 2017) .

Table 1 shows effect of agriculture, forestry and fisheries on the supply of food and raw materials in Deli Serdang Regency. The Agriculture Sector in Deli Serdang Regency has the fourth-largest Gross Regional Domestic Product (GRDP) distribution in 2016 (10.83\%), below the manufacturing sector (32\%) trade (16.19\%) and buildings (15.33\%) (BPS, 2017). 
Table 1. Gross Regional Domestic Product of Deli Serdang Regency Based on 2010 Current Price by Business Field (percent), 2012-2016

\begin{tabular}{|c|c|c|c|c|c|c|}
\hline \multirow{2}{*}{ No } & Business field & \multicolumn{5}{|c|}{ Year } \\
\cline { 3 - 7 } & & 2012 & 2013 & 2014 & 2015 & 2016 \\
\hline 1 & Agriculture, forestry and fisheries & 13,62 & 12,82 & 11,72 & 11,18 & 10,83 \\
\hline 2 & Mining & 0,90 & 0,84 & 0,77 & 0,78 & 0,77 \\
\hline 3 & Processing industry & 36,08 & 33,79 & 32,67 & 32,34 & 32,00 \\
\hline 4 & Electricity and gas supply & 0,15 & 0,13 & 0,12 & 0,12 & 0,11 \\
\hline 5 & Water supply, waste management & 0,05 & 0,05 & 0,05 & 0,05 & 0,05 \\
\hline 5 & Building & 15.30 & 15,15 & 14,99 & 15,16 & 15,33 \\
\hline 6 & Wholesale and retail trade & 16,51 & 15,98 & 15,59 & 15,90 & 16,19 \\
\hline 7 & Warehousing transportation & 1,99 & 5,84 & 8,96 & 9,12 & 9,24 \\
\hline 8 & Provider of accommodation and eating and & 2,59 & 2,54 & 2,55 & 2,60 & 2,62 \\
\hline 9 & drinking & 1,41 & 1,28 & 1,17 & 1,14 & 1,11 \\
\hline 10 & Information and communication & 2,75 & 3,02 & 2,86 & 2,88 & 2,90 \\
\hline 11 & Financial and insurance services & 3,20 & 3,33 & 3,35 & 3,51 & 3,66 \\
\hline 12 & Real estate & 0,44 & 0,42 & 0,42 & 0,43 & 0,44 \\
\hline 13 & Company services & 2,17 & 2,05 & 2,04 & 2,05 & 2,00 \\
\hline 14 & Government administration & 1,69 & 1,63 & 1,60 & 1,57 & 1,55 \\
\hline 15 & Educational services & 0,88 & 0,86 & 0,87 & 0,90 & 0,93 \\
\hline 16 & Health services & 0,27 & 0,27 & 0,27 & 0,28 & 0,28 \\
\hline
\end{tabular}

(Source: GRDP According to Deli Serdang Regency Business Field 2012-2016)

The agriculture sector in Deli Serdang Regency is divided into five sub-sectors namely estate crops, horticultural crops, food, livestock, forestry, and agricultural and hunting services. The distribution of each of these sub-sectors to the economy in Deli Serdang Regency can be seen in Table 2 .

Table 2. Contribution of Agriculture Subsector to Deli Serdang Regency GRDP Based on 2010 Current Price by Business Field (percent), 2012-2016

\begin{tabular}{|c|c|c|c|c|c|c|}
\hline \multirow{2}{*}{ No } & Business field & \multicolumn{4}{|c|}{ Year } \\
\cline { 3 - 6 } & & 2012 & 2013 & 2014 & 2015 & 2016 \\
\hline \multirow{2}{*}{1} & $\begin{array}{c}\text { Agriculture, Animal Husbandry, Plantation and } \\
\text { Agricultural Services }\end{array}$ & 88,64 & 88,30 & 87,48 & 86,63 & 86,55 \\
\hline & a. Crops & 24,28 & 24,26 & 23,72 & 24,50 & 25,16 \\
\hline & b. Horticultural Plants & 15,91 & 15,82 & 15,31 & 15,09 & 14,53 \\
\hline & c. Plantation & 30,67 & 30,51 & 29,85 & 28,07 & 27,78 \\
\hline & d. Animal husbandry & 16,93 & 16,85 & 17,71 & 18,08 & 18,19 \\
\hline & e. Agriculture and Hunting Services & 0,84 & 0,86 & 0,89 & 0,90 & 0,89 \\
\hline 2. & Forestry & 1,31 & 1,30 & 1,37 & 1,40 & 1,37 \\
\hline 3. & Fisher & 10,06 & 10,40 & 11,15 & 11,97 & 12,08 \\
\hline
\end{tabular}

(Source: GRDP According to Deli Serdang Regency Business Field 2012-2016)

Table 2 shows the first largest distribution of GRDP in the estate crops sub-sector in 2016, which was 27.78 percent while the second contribution was food crops 25.16 percent. This plantation crops are the mainstay subsector compared to other subsectors. 
Deli Serdang Regency is one of the plantation centers in North Sumatra. Important commodities produced in Deli Serdang Regency are rubber, oil palm, cocoa and coconut. The development of the estate crops sub-sector is inseparable from the distribution of the estate crops sub-sector at a smaller scope, namely the sub-district area. Deli Serdang Regency is administratively divided into 22 subdistricts namely Gunung Meriah, STM Hulu, Sibolangit, Kutalimbaru, Pancur Batu, Namo Rambe, Biru-Biru, STM Hilir, Bangun Purba, Galang, Tanjung Morawa, Patumbak, Deli Tua, Sunggal, Hamparan Perak, Labuhan Deli, Percut Sei Tuan, Batang Kuis, Pantai Labu, Beringin, Lubuk Pakam, and Pagar Merbau, each of which has different natural resources (BPS, 2017). The Commodities included in the estate crops sub-sector, and the production of each of these plantation crops can be seen in Table 3 .

Table 3. Production of Smallholder Crops by Type of Plants in Deli Serdang District (ton) in 2012-2016

\begin{tabular}{|c|c|c|c|c|c|c|}
\hline \multirow{2}{*}{ No } & \multirow{2}{*}{ Type of Plant } & \multicolumn{5}{|c|}{ Production Year (ton) } \\
\cline { 3 - 7 } & & $\mathbf{2 0 1 2}$ & $\mathbf{2 0 1 3}$ & $\mathbf{2 0 1 4}$ & $\mathbf{2 0 1 5}$ & $\mathbf{2 0 1 6}$ \\
\hline 1 & Rubber & $5.346,46$ & $5.447,17$ & $6.458,55$ & $6.865,49$ & $6.870,93$ \\
\hline 2 & Coconut & $3.214,49$ & $2.809,77$ & $2.955,00$ & $3.044,95$ & $3.045,15$ \\
\hline 3 & Palm oil & $179.183,89$ & $187.169,09$ & $203.472,59$ & $210.232,95$ & $210.303,00$ \\
\hline 4 & Coffee & 539,56 & 501,50 & 660,00 & - & 307,00 \\
\hline 5 & Cocoa & $4.156,09$ & $3.796,71$ & $4.414,02$ & $4.161,37$ & $4.190,84$ \\
\hline 6 & Sweet skin & 73,93 & 73,93 & 80,00 & 73,93 & 74,67 \\
\hline 7 & Areca nut & $1.272,92$ & $1.276,07$ & $1.297,00$ & $1.392,60$ & $1.395,85$ \\
\hline 8 & Candlenut & 474,79 & 478,36 & 493,00 & 510,85 & 519,01 \\
\hline 9 & Gambir & 12,25 & 8,23 & 7,50 & 15,00 & 16,80 \\
\hline 10 & Sugar palm & 354,16 & 357,10 & 362,00 & 358,69 & 364,66 \\
\hline 11 & Cane & $1.448,16$ & $1.130,00$ & $1.103,00$ & $1.703,00$ & $2.242,00$ \\
\hline
\end{tabular}

(Source: North Sumatra Plantation Office 2012-2016)

Table 3 shows that rubber production increased from $6,865.49$ tons in 2015 to $6,870.93$ tons in 2016. Smallholder oil palm plantations were planted in all districts in Deli Serdang Regency. Palm oil production in 2015 amounted to 210,232.95 tons, where in 2016 oil palm production amounted to 210,303.00 tons. Other plantation crops such as coconut, coffee, areca nut, candlenut, gambier and sugar cane in 2016 also experienced an increase in production.

Base activities are all activities that produce products and service providers that bring money from outside the region. While non-base activities are activities to meet local consumption needs. An area is in need of a variety of data that can be used as a basis for reference, both in the preparation of evaluations of economic development in the regions that have been implemented and in the formulation of planning in the future. Therefore every local government must know the basic commodities. Because this is very closely related to the improvement of regional development and mature planning strategies. Therefore, the researcher raised the title "People's Plantation Plant Base Sector in Each District of Deli Serdang District" with the problem being what commodity plantations are the basis in each of the districts of Deli Serdang Regency.

\section{METHODOLOGY}

\subsection{Method of Determination of Research Areas}

The research area was chosen purposively, meaning that the study area was determined based on certain considerations adjusted to the research objectives. Considering the agriculture 
sector in 2016 is ranked fourth giving a distribution of 10.83 percent of the Deli Serdang Regency's GRDP and the distribution of the estate crops subsector in 2012-2016 ranks first out of the five other agricultural subsectors.

\subsection{Sample Determination Method}

The method used in this study is the census method. The census method is a method of determining the sample in which all populations are sampled so that 22 Subdistricts in Deli Serdang Regency are sampled (Arikunto, 2005).

\subsection{Method of Collecting Data}

In this research the data collection technique used is secondary data collection. Secondary data is data obtained indirectly through literature studies in the form of notes / reports or books issued by an agency or company. In collecting secondary data in this study the author uses the method of documentation that is by collecting data by looking for data about the studied variables in the form of records or documentation obtained (Mangkoedihardjo, 2007, 2012; Waremra and Betaubun, 2018; Pratama et al., 2019).

\subsection{Data Analysis Method}

Calculate base sectors by using Location Quotient (LQ) analysis. (Tarigan, 2003)

$$
L Q=\frac{V_{i w} / V_{t w}}{V_{i r} / V_{t r}}
$$

Information:

LQ: Location Quotient Index of agricultural commodities in Deli Serdang Regency

Viw: Production of estate crops i in sub-district of Deli Serdang Regency

Vtw: Total Production of plantation commodity in sub-district of Deli Serdang Regency

Vir: Production of estate crops i in Deli Serdang Regency

Vtr: Total Production of plantation commodity in Deli Serdang Regency

If:

LQ> 1: Is a basic commodity and has the potential for export

LQ $<1$ : Is a non-base commodity (local / import sector) (Widodo, 2006)

\section{RESULTS AND DISCUSSION}

\subsection{Results}

Deli Serdang Regency consists of 22 sub-districts with the widest sub-district is Hamparan Perak sub-district which is $230.15 \mathrm{~km}^{2}$, while the smallest sub-district is Deli Tua which is $9.36 \mathrm{~km}^{2}$

Table 4. Area of Deli Serdang Regency by District in 2016

\begin{tabular}{|c|c|c|c|}
\hline No & Districts & Large $\left(\mathrm{km}^{2}\right)$ & Percentage \\
\hline 1 & Gunung Meriah & 76,65 & 3,07 \\
\hline 2 & S.T.M Hulu & 223,38 & 8,94 \\
\hline 3 & Sibolangit & 179,96 & 7,20 \\
\hline 4 & Kutalimbaru & 174,92 & 7,00 \\
\hline 5 & Pancur Batu & 122,53 & 4,91 \\
\hline 6 & Namo Rambe & 62,30 & 2,49 \\
\hline
\end{tabular}


The Base Sector of Community Plantation Plant

\begin{tabular}{|c|c|c|c|}
\hline 7 & Biru-Biru & 89,69 & 3,59 \\
\hline 8 & S.T.M.Hilir & 190,50 & 7,63 \\
\hline 9 & Bangun Purba & 129,95 & 5,20 \\
\hline 10 & Galang & 150,29 & 6,02 \\
\hline 11 & Tanjung Morawa & 131,75 & 5,27 \\
\hline 12 & Patumbak & 46,79 & 1,87 \\
\hline 13 & Deli Tua & 9,36 & 0,37 \\
\hline 14 & Sunggal & 92,52 & 3,70 \\
\hline 15 & Hamperan Perak & 230,15 & 9,21 \\
\hline 16 & Labuhan Deli & 127,23 & 5,09 \\
\hline 17 & Percut Sei Tuan & 190,79 & 7,64 \\
\hline 18 & Batang Kuis & 40,34 & 1,62 \\
\hline 19 & Pantai Labu & 81,85 & 3,28 \\
\hline 20 & Beringin & 52,69 & 2,11 \\
\hline 21 & Lubuk Pakam & 31,19 & 1,25 \\
\hline 22 & Pagar Merbau & 62,89 & 2,52 \\
\hline & Deli Serdang & $2.497,72$ & 100 \\
\hline
\end{tabular}

(Source: BPS, 2017)

\subsubsection{Population and Labor}

\subsection{Population}

The total population of Deli Serdang in June 2016 is estimated to be 2,072,521 people consisting of 1,043,114 men and 1,029,407 women spread in 22 districts where the largest population is in Percut Sei Tuan District 445,223 people, while the number the smallest population in Gunung Meriah District is 2,949 inhabitants.

Table 5. Population by Sub-District and Gender Deli Serdang Regency in 2016

\begin{tabular}{|c|c|c|c|c|}
\hline No & Districts & Men & Woman & Total \\
\hline 1 & Gunung Meriah & 1.477 & 1.472 & 2.949 \\
\hline 2 & S.T.M Hilir & 7.202 & 7.125 & 14.327 \\
\hline 3 & Sibolangit & 11.469 & 11.539 & 23.008 \\
\hline 4 & Kutalimbaru & 20.673 & 20.876 & 41.549 \\
\hline 5 & Pancur Batu & 49.243 & 49.124 & 98.367 \\
\hline 6 & Namo Rambe & 20.940 & 21.406 & 42.346 \\
\hline 7 & Biru-Biru & 19.833 & 19.665 & 39.498 \\
\hline 8 & S.T.M.Hilir & 18.055 & 17.498 & 35.553 \\
\hline 9 & Bangun Purba & 12.353 & 12.551 & 25.086 \\
\hline 10 & Galang & 35.928 & 35.592 & 71.520 \\
\hline 11 & Tanjung Morawa & 112.281 & 110.353 & 222.634 \\
\hline 12 & Patumbak & 51.952 & 50.518 & 102.470 \\
\hline 13 & Deli Tua & 34.524 & 35.573 & 70.097 \\
\hline 14 & Sunggal & 142.031 & 139.978 & 282.009 \\
\hline 15 & Hamperan Perak & 88.310 & 85.398 & 173.708 \\
\hline 16 & Labuhan Deli & 35.430 & 34.225 & 69.655 \\
\hline 17 & Percut Sei Tuan & 223.927 & 221.296 & 445.223 \\
\hline 18 & Batang Kuis & 33.019 & 32.071 & 65.090 \\
\hline 19 & Pantai Labu & 25.744 & 24.194 & 49.938 \\
\hline
\end{tabular}


Nina Maksimiliana Ginting and Philipus Betaubun

\begin{tabular}{|c|c|c|c|c|}
\hline 20 & Beringin & 30.851 & 29.989 & 60.840 \\
\hline 21 & Lubuk Pakam & 46.598 & 47.435 & 94.033 \\
\hline 22 & Pagar Merbau & 21.092 & 21.529 & 42.621 \\
\hline & Districts Deli Serdang & 1.043 .114 & 1.029 .407 & 2.072 .521 \\
\hline
\end{tabular}

(Source: BPS Deli Serdang 2017)

\subsubsection{Labor}

In 2015 in Deli Serdang District there were 865,897 workforce residents consisting of 810,620 people (93.6 percent) categorized as working and 55,277 people (6.4 percent) categorized as looking for work and not working.

The location quetient (LQ) approach is used to calculate the LQ value of each community plantation commodity produced in Deli Serdang District. Criteria for estate crop commodities which are the basis are commodities that have a value of $L Q>1$, while the commodities of community estate crops that are non-base are estate crop commodities with a value of $L Q<1$.

Base plantation commodities in each of Deli Serdang Districts in 2012-2016 based on the results of the average LQ analysis can be seen in the following Table 6.

Table 6. Smallholder Plantations Commodity in Each District of Deli Serdang District in 2012-2016

\begin{tabular}{|c|c|c|c|c|c|c|c|c|c|c|c|c|}
\hline \multirow[b]{2}{*}{$\begin{array}{l}\mathrm{N} \\
\mathrm{O}\end{array}$} & \multirow[b]{2}{*}{ Districts } & \multicolumn{8}{|c|}{ Base Plantation Commodity } & \multirow[b]{2}{*}{$\begin{array}{l}\text { Sugar } \\
\text { Palm }\end{array}$} & \multirow[b]{2}{*}{$\begin{array}{c}\text { Can } \\
\mathrm{e}\end{array}$} & \multirow{2}{*}{$\begin{array}{c}\text { Numbe } \\
\text { r of } \\
\text { Base } \\
\text { Plantati } \\
\text { on } \\
\text { Plants }\end{array}$} \\
\hline & & $\begin{array}{c}\text { Rubb } \\
\text { er }\end{array}$ & $\begin{array}{c}\text { Cocon } \\
\text { ut }\end{array}$ & $\begin{array}{c}\text { Coff } \\
\text { ee }\end{array}$ & $\begin{array}{c}\text { Kak } \\
\text { ao }\end{array}$ & $\begin{array}{l}\text { Sweet } \\
\text { Skin }\end{array}$ & $\begin{array}{c}\text { Areca } \\
\text { Nut }\end{array}$ & $\begin{array}{c}\text { candle } \\
\text { nut }\end{array}$ & $\underset{\text { bir }}{\mathrm{Gam}}$ & & & \\
\hline 1 & $\begin{array}{c}\text { Bangun } \\
\text { Purba }\end{array}$ & 7,19 & - & - & 2,52 & - & - & 1,5 & - & 1,72 & - & 4 \\
\hline 2 & Batang Kuis & - & 12,33 & - & 8,72 & - & - & - & - & - & - & 2 \\
\hline 3 & Beringin & 1,36 & 69,26 & - & $\begin{array}{c}11,7 \\
7\end{array}$ & - & 27,48 & - & - & - & - & 4 \\
\hline 4 & Biru-Biru & 4,04 & 2,45 & - & 17,3 & - & 1,3 & 2,9 & - & - & - & 5 \\
\hline 5 & Deli Tua & - & 70,45 & - & $\begin{array}{c}26,2 \\
9\end{array}$ & - & - & - & - & - & - & 2 \\
\hline 6 & Galang & 4,82 & 6,01 & - & 2,14 & - & - & - & - & - & - & 3 \\
\hline 7 & $\begin{array}{c}\text { Gunung } \\
\text { Meriah } \\
\end{array}$ & 6,66 & 1,08 & $\begin{array}{c}39,8 \\
7 \\
\end{array}$ & 4,74 & 27,85 & - & 6,92 & - & - & - & 6 \\
\hline 8 & $\begin{array}{c}\text { Hamparan } \\
\text { Perak }\end{array}$ & - & 6,92 & - & 1,3 & - & - & - & - & - & $\begin{array}{l}16 \\
53\end{array}$ & 3 \\
\hline 9 & Kutalimbaru & 3,52 & 3,23 & 1,14 & 4,99 & - & 14,68 & 10,08 & - & 6,99 & $\begin{array}{c}7,9 \\
4\end{array}$ & 8 \\
\hline 10 & $\begin{array}{c}\text { Labuhan } \\
\text { Deli }\end{array}$ & - & 4,36 & - & - & - & 1,09 & - & - & 1,11 & - & 3 \\
\hline 11 & $\begin{array}{l}\text { Lubuk } \\
\text { Pakam }\end{array}$ & - & 29,61 & - & 6,3 & - & 69,27 & - & - & - & - & 3 \\
\hline 12 & Namorambe & 1,28 & 8,71 & 2,27 & $\begin{array}{c}10,8 \\
5\end{array}$ & - & 7,84 & 20,9 & - & 36,73 & - & 7 \\
\hline 13 & $\begin{array}{c}\text { Pagar } \\
\text { Merbau }\end{array}$ & 2,81 & 10,02 & - & 5,28 & - & 9,33 & - & - & 11,37 & - & 5 \\
\hline 14 & Pancur Batu & 1,59 & 11,73 & - & 6,74 & - & 7,58 & 3,03 & - & 6,02 & - & 6 \\
\hline 15 & Pantai Labu & - & 2,99 & - & 4,1 & - & 1,28 & - & - & - & - & 3 \\
\hline 16 & Patumbak & 2,14 & 2,41 & - & $\begin{array}{c}10,5 \\
8\end{array}$ & - & - & - & - & - & - & 3 \\
\hline 17 & $\begin{array}{c}\text { Percut Sei } \\
\text { Tuan }\end{array}$ & - & 4,88 & - & - & - & 1,4 & - & - & - & - & 2 \\
\hline 18 & Sibolangit & 6,29 & 2,41 & $\begin{array}{c}43,9 \\
4\end{array}$ & $\begin{array}{c}18,3 \\
8\end{array}$ & 56,54 & 21,66 & 31,99 & 126,1 & 51,74 & - & 9 \\
\hline
\end{tabular}


The Base Sector of Community Plantation Plant

\begin{tabular}{|c|c|c|c|c|c|c|c|c|c|c|c|c|}
\hline 19 & STM Hilir & 2,57 & 1,13 & - & 2,07 & - & 1,79 & 2,02 & - & 2,97 & - & 6 \\
\hline 20 & STM Hulu & 8,69 & & 1,39 & - & 6,54 & - & 3,46 & 5,79 & - & - & 5 \\
\hline 21 & Sunggal & - & 19,62 & - & $\begin{array}{c}15,1 \\
1\end{array}$ & - & 7,47 & - & - & - & $\begin{array}{c}33 \\
2\end{array}$ & 4 \\
\hline 22 & $\begin{array}{l}\text { Tanjung } \\
\text { Merawa }\end{array}$ & 4,22 & 7,55 & - & 2,87 & - & 3,49 & - & - & 2,18 & - & 5 \\
\hline & Total & 14 & 20 & 5 & 19 & 3 & 14 & 9 & 2 & 9 & 3 & 98 \\
\hline
\end{tabular}

\subsection{Discussion}

Data of smallholder plantations in each district in Deli Serdang Regency in 2012-2016 based on the results of the average LQ analysis in Table 6 shows that based on the identification of smallholder plantations which are the basis in each sub-district of Deli Serdang Regency, namely: rubber, coconut, coffee , cocoa, cinnamon, areca nut, hazelnut, gambier, sugar palm and sugar cane.

Rubber commodities are found in Bangun Purba, Beringin, Biru-Biru, Galang, Gunung Meriah, Kutalimbaru, Namorambe, Pagar Merbau, Pancur Batu, Patumbak, Sibolangit, STM Hilir, STM Hulu and Tanjung Merawa Districts. Coconut commodities are found in Batang Kuis District, Beringin, Biru-Biru, Deli Tua, Galang, Gunung Meriah, Hamparan Perak, Kutalimbaru, Labuhan Deli, Lubuk Pakam, Namorambe, Pagar Merbau, Pancur Batu, Pantai Labu, Patumbak, Percut Sei Tuan, Sibolangit, STM Hilir, Sunggal and Tanjung Merawa District. Coffee commodities are found in the districts of Gunung Meriah, Kutalimbaru, Namorambe, Sibolangit, and STM Hulu. Cacao commodities are found in the Bangun Purba District, Batang Kuis, Beringin, Biru-Biru, Deli Tua, Galang, Gunung Meriah, Hamparan Perak, Kutalimbaru, Lubuk Pakam, Namorambe, Pagar Merbau, Pancur Batu, Pantai Labu, Patumbak, Sibolangit, STM Hilir, Sunggal and Tanjung Merawa Districts. The cinnamon commodity is located in Gunung Meriah, Sibolangit and STM Hulu Districts. Betel commodities are found in Beringin, Biru-Biru, Labuhan Deli, Lubuk Pakam, Namorambe, Pagar Merbau, Pancur Batu, Pantai Labu, Percut Sei Tuan, Sibolangit, STM Hilir, Sunggal and Tanjung Merawa District. Candlenut commodities are found in Bangun Purba District, Biru-Biru, Gunung Meriah, Kutalimbaru, Namorambe, Pancur Batu, Sibolangit, STM Hilir and STM Hulu District. Gambier commodities are in Sibolangit District and STM Hulu District. Sugar palm commodities are found in Bangun Purba District, Kutalimbaru, Labuhan Deli, Namorambe, Pagar Merbau, Pancur Batu, Sibolangit, STM Hilir and Tanjung Merawa District. Sugar cane commodities are found in Hamparan Perak, Kutalimbaru and Sunggal Districts.

The sub-district which has the most commodity base plantations is Sibolangit District, which is nine estate crop commodities. Whereas the least possessed of estate crop plantation commodities are Batang Kuis District, Deli Tua and Percut Sei Tuan.

\section{CONCLUSION}

Commodities of smallholder plantations which are the basis of each district in Deli Serdang Regency, namely rubber commodities, are found in fourteen districts. Coconut commodities are found in twenty sub-districts. Coffee commodity is available in five districts. Cacao is available in nineteen districts. The cinnamon commodity is found in three districts. Betel commodity is found in fourteen districts. Candlenut commodity is found in nine districts. Gambier commodity is found in two sub-districts. Sugar palm commodities are in nine districts. Sugar cane commodity is found in three districts. 


\section{REFERENCES}

[1] Arikunto, Metodologi Penelitian. Jakarta: UI Press, 2005

[2] Arsyad, L, Ekonomi Pembangunan. Bagian Penerbitan STIE YKPN. Yogyakarta, 2004

[3] BPS, Kabupaten Deli Serdang dalam Angka 2017. Deli Serdang, 2017

[4] Budiharsono, S, Teknik Analisis Pembangunan Wilayah Pesisir dan Lautan, 2005

[5] Pradnya Paramita. Jakarta.

[6] Dinas Perkebunan, Laporan Perkebunan Rakyat, Kabupaten Deli Serdang, Dinas Perkebunan Sumatera Utara, 2012

[7] Laporan Perkebunan Rakyat, Kabupaten Deli Serdang, Dinas Perkebunan Sumatera Utara, 2013

[8] Laporan Perkebunan Rakyat, Kabupaten Deli Serdang, Dinas Perkebunan Sumatera Utara, 2014

[9] Laporan Perkebunan Rakyat, Kabupaten Deli Serdang, Dinas Perkebunan Sumatera Utara, 2015

[10] Laporan Perkebunan Rakyat, Kabupaten Deli Serdang, Dinas Perkebunan Sumatera Utara, 2016

[11] Fatah, Dinamika Pembangunan Pertanian \& Pedesaan.Banjar Baru: Pustaka Barus, 2006

[12] Mangkoedihardjo, S, Leaf Area for Phytopumping of Wastewater. Applied Ecology and Environmental Research 5 (1), 2007, pp 37-42.

[13] Mangkoedihardjo, S. and April, SAL, Compost on Evapotranspiration Bed Planted With Yellow Flag for Treatment of Wastewater Containing Anionic Surfactant. Journal of Applied Sciences Research, 8(3), 2012, pp 1630-1633.

[14] Nasra Pratama, Fransiskus Xaverius Manggau, Philipus Betaubun, Attitude Quadrotor Control System with Optimization of PID Parameters Based On Fast Genetic Algorithm. International Journal of Mechanical Engineering and Technology, 10(1), 2019, pp 335-343.

[15] Richard S. Waremra and Philipus Betaubun, Analysis of Electrical Properties Using the four point Probe Method. E3S Web of Conferences 73, 2018, pp 13019.

[16] Rahardi, Agribisnis Tanaman Perkebunan. Penebar Swadaya. Jakarta, 1993

[17] Saragih,Jef Rudianto, Perencanaan Wilayah dan Pengembangan Ekonomi Lokasi Berbasis Pertanian.Penerbit Pustaka Belajar. Yogyakarta, 2015

[18] Sitorus, Nurmely, Analisis Penentuan Komoditi Perkebunan Basis di Wilayah Masing-Masing Kecamatan di Kabupaten Simalungun. Universitas Sumatera Utara, 2014

[19] Sukirno, Sadono, Makroekonomi Teori Pengantar. Edisi Ketiga. Jakarta. PT Raja Grafindo Persada, 2016

[20] Sultoni, Hamdan, Analisis Subsektor Pertanian Basis Dan Komponen Pertumbuhan Tanaman Bahan Makanan Di Provinsi Jawa Tengah. Skripsi. Jurusan Sosial Ekonomi Pertanian. Fakultas Pertanian Universitas Sebelas Maret. Surakarta, 2009

[21] Tarigan, R., Ekonomi Regional. Jakarta: Bumi Aksara, 2003

[22] Widodo, T, Perencanaan Pembangunan: Aplikasi Komputer (Era Otonomi Daerah). Yogyakarta: UPP STIM YKPN, 2006 